\title{
The role of eicosanoids in renal diseases - potential therapeutic possibilities
}

\author{
Maciej Fijałkowski, Joanna Stępniewska, Maciej Domański, Kazimierz Ciechanowski \\ and Edyta Gołembiewska ${ }^{\bowtie}$
}

Department of Nephrology, Transplantology and Internal Medicine, Pomeranian Medical University, Szczecin, Poland

Eicosanoids are biologically active molecules that are created in the process of oxidation of arachidonic acid (AA) which is a constituent of the cell membrane phospholipids. Throughout the years it was evidenced by experiments that the lipid and lipid-derived metabolites play an important role in physiological and pathological processes in the kidneys. They are being considered as biomarkers in detecting acute kidney injury, nephrotoxicity, glomerulonephritis and early stages of diabetic nephropathy because of their participation in inflammatory processes and in oxidative stress. They might be also considered as potential novel targets of therapy. However, the role of eicosanoids is still not fully clear and needs to be explored in future studies. In this brief review, studies on the role of eicosanoids in physiological and pathological conditions, e.g. acute kidney injury (AKI) and chronic kidney disease (CKD), and in different renal replacement therapies, including kidney transplantation, are being discussed.

Key words: eicosanoids, acute kidney injury, chronic kidney disease, dialysis, renal transplantation

Received: 02 May, 2018; revised: 30 August, 2018; accepted: 02 October, 2018; available on-line: 19 November, 2018

e-mail: irys@pum.edu.pl

Abbreviations: AKI, acute kidney injury; AQP2, aquaporin 2; AQP3, aquaporin 3; AA, arachidonic acid; ADPKD, autosomal dominant polycystic kidney disease; CVD, cardiovascular disease; CKD, chronic kidney disease; c-AUCB, cis-4-[4-(3-adamantan-1-ylureido)-cyclohexyloxy]-benzoic acid; CTGF, connecting tubule- glomerular feedback; COX, cyclooxygenase; cAMP, cyclic adenosine monophosphate; CYP 450, cytochrome P-450; CPLA2, cytosolic phospholipase A2; ESRD, end-stage renal disease; eNaC, epithelial sodium channel; EET, epoxyeicosatrienoic acid; EPO, erythropoietin; eGFR, estimated glomerular filtration rate; HETE, hydroxyeicosatetraenoic acid; HPETE, hydroperoxyeicosatetraenoic acid; LTA4, leukotriene A4; LTB4, leukotriene B4; LOX, lipoxygenase; NSAID, nonsteroidal anti-inflammatory drug; PD, peritoneal dialysis; PGD2, prostaglandin D2; PGE2, prostaglandin E2; PGF2, prostaglandin F2; PGI2, prostaglandin 12; ROS, reactive oxygen species; TXA2, thromboxane $A 2$; TXB2, thromboxane B2; TGF-beta, transforming growth factor-beta; TNF, tumor necrosis factor; XNDI, X-linked nephrogenic diabetes insipidus

\section{INTRODUCTION}

Eicosanoids are biologically active molecules generated in the process of oxidation of arachidonic acid (AA) which is a constituent of cell membrane phospholipids. Similarly to AA, the eicosanoid chain is created from 20 carbon atoms. Phospholipase A2 (cPLA $)$, a cytosolic enzyme, catalyzes the hydrolysis of ester bonds of phospholipids and releases free AA, which is then converted into eicosanoids (Smith \& Murphy, 2002). There are three main metabolic pathways involved in the eicosanoid production and catalyzed by the following enzymes: cyclooxygenase (COX), which converts $\mathrm{AA}$ to prostanoids (prostaglandins, prostacyclins and thromboxanes), lipoxygenase (LOX) which first converts AA into the hydroperoxyeicosatetraenoic acid (HPETE), and then gives rise to leukotriens, lipoxines and 5-, 12-, 15-hydroxyeicosatetraenoic acid (HETE). And last but not least, AA is converted into epoxyeicosatrienoic acids (EETs) and 20-HETE via the cytochrome P-450 monooxygenase (CYP 450) pathway. AA may also undergo non-enzymatic peroxidation to isoprostanes (Burdan et al., 2006; Câmara et al., 2009; Sałata \& Dołęgowska, 2014).

Here, we review the role of eicosanoids in physiology and pathological conditions, e.g. acute kidney injury (AKI) and chronic kidney disease (CKD), and in different renal replacement therapies, including kidney transplantation. Major findings in the experimental and clinical studies on the role of eicosanoids are presented in Table 1. Metabolism of arachidonic acid and potential therapeutic possibilities are shown in Fig. 1.

\section{PHYSIOLOGY OF EICOSANOIDS IN THE KIDNEYS}

\section{The COX pathway}

Among the prostanoids, the most important biological activity in the kidneys is held by prostaglandin D2 (PGD2), prostaglandin E2 (PGE2) and prostaglandin F2 (PGF2) (Sałata \& Dołegowska, 2014). There are 3 forms of cyclooxygenase described in the literature. COX 1 is a constitutive enzyme that takes part in the maintenance of homeostasis, but it is also expressed in pathological conditions, such as cervical tumors and the Alzheimer's disease (Sales et al., 2002; Sales \& Jabbour, 2003; Hoozemans et al., 2008). There is a high concentration of this enzyme in the renal collecting duct epithelial cells and vascular smooth muscles cells. COX 2 is an induced isoform of cyclooxygenase and is mainly associated with inflammation. When it comes to kidneys, it is mainly produced in the glomerulus, cells of renal papilla, and especially in the medullary interstitial cells, macula densa and ascending limb of Henle's loop (Câmpean et al., 2003; Burdan et al., 2006; Sałata \& Dołęowska, 2014; Nørregaard et al., 2015). The third isoform - COX 3 - which is a post-transcriptional modification of COX 1 , is selectively inhibited by paracetamol and can act as a regulator in the thermoregulatory center of the brain (Schwab et al., 2003; Câmara et al., 2009). PGE2 is the major prostaglandin expressed in the kidneys. It is produced by 3 isoforms of the prostaglandin E synthase- 


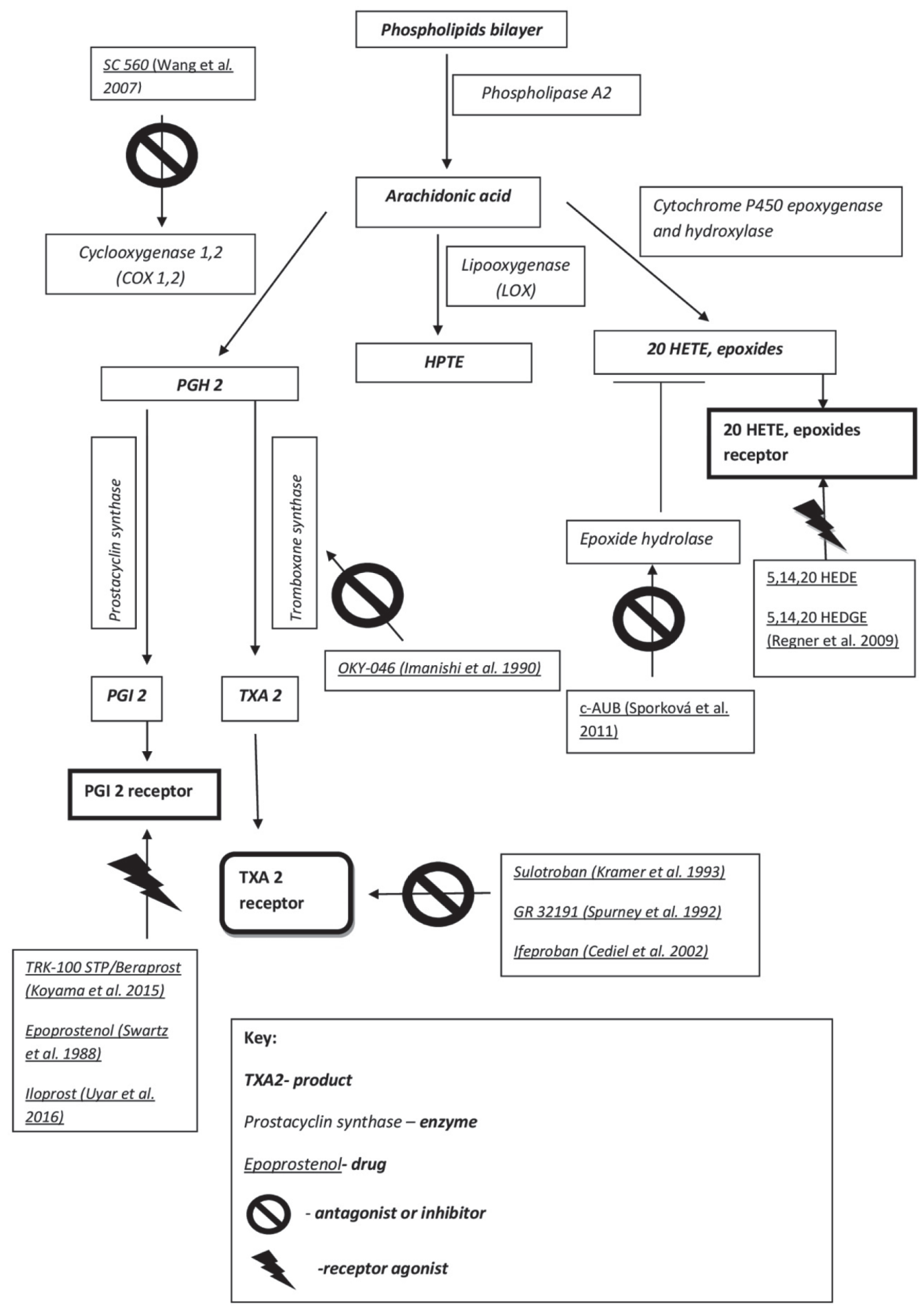

Figure 1. Metabolism of arachidonic acid and potential therapeutic possibilities

Abbreviations: COX, cyclooxygenase; HEDE, 20-hydroxyeicosa-5(Z), 14(Z)-dienoic acid; HEDGE, N-[20-hydroxyeicosa-5(Z),14(Z)-dienoyl] glycine; HETE, hydroxyeicosatetraenoic acid; HPETE, hydroperoxyeicosatetraenoic acid; LOX, lipoxygenase; PGH2, prostaglandin H2; PGI2, prostaglandin 12; TXA2 thromboxane A2

two microsomal and one cytosolic synthases. PGE 2 regulates the function of kidneys through its four receptors - EP1-4 (Regner, 2012; Nasrallah et al., 2014). They play an important role in inhibiting sodium and water reabsorption, regulation of glomerular hemodynamics and blood pressure (Nørregaard et al., 2015). Stimulation of EP2 and EP 4 receptors can promote urinary concentra- tion. Studies on rats with $\mathrm{X}$-linked nephrogenic diabetes insipidus (XNDI) suggested that EP2 and EP4 agonists increase water channel aquaporin-2 phosphorylation and can partially compensate for a nonfunctional vasopressin type-2 receptor (Olesen et al., 2011). Another study on mice had shown that selective EP4 receptor agonists may reduce all major manifestations of XNDI, includ- 
Table 1. Experimental and clinical studies on the roles of eicosanoids in the kidney diseases

\begin{tabular}{|c|c|c|}
\hline First author, year & Model/Population & Main findings \\
\hline (Badr et al., 1986) & Rats & $\begin{array}{l}\text { E. coli endotoxin may be responsible for decreasing eGFR and filtration } \\
\text { fraction by stimulation of the TXA2 biosynthesis and other products of cyc- } \\
\text { looxygenase metabolism in the kidney. }\end{array}$ \\
\hline $\begin{array}{l}\text { (Chatziantoniou et al., 1990; } \\
\text { Badahman \& Wilson, 1994; } \\
\text { Cediel et al., 2002) }\end{array}$ & Rats & $\begin{array}{l}\text { TXA2 may contribute to renal vasoconstriction. Inhibition of TXA2 produc- } \\
\text { tion results in vasodilatation. }\end{array}$ \\
\hline $\begin{array}{l}\text { (Chaudhari \& Kirschenbaum, } \\
\text { 1983) }\end{array}$ & Rabbits & $\begin{array}{l}\text { The concentration of PGE2 in cortical tissue of kidneys is increased in AKI } \\
\text { because of its decreased metabolism. }\end{array}$ \\
\hline (Jia et al., 2012) & Mice & $\begin{array}{l}\text { PGE2 increases EPO concentration and decreases anemia after renal mass } \\
\text { reduction. It also increases the inflammatory state and provokes renal dys- } \\
\text { function. }\end{array}$ \\
\hline (Kramer et al., 1993) & Rats & $\begin{array}{l}\text { Sulotroban can stop TXA2 dependent vasoconstriction in the early phase } \\
\text { of AKI. }\end{array}$ \\
\hline (Li et al., 2009) & Mice & $\begin{array}{l}\text { Selective EP4 receptor agonists may reduce all major manifestations of } \\
\text { XNDI, including changes in renal morphology, and may become a new } \\
\text { treatment strategy for hereditary nephrogenic diabetes insipidus. }\end{array}$ \\
\hline (Makino et al., 2002) & Rats & $\begin{array}{l}\text { Inhibition of EP1 receptor may prevent the progression of diabetic nephro- } \\
\text { pathy. }\end{array}$ \\
\hline (Mangino et al., 1987) & Dogs & $\begin{array}{l}\text { 12-HETE are biosynthesized in higher amounts by renal cortical tissue } \\
\text { which undergoes rejection. }\end{array}$ \\
\hline (Mederle et al., 2015) & Mice & $\begin{array}{l}\text { Decreased activity of COX } 1 \text { after administration of its inhibitor, called SC- } \\
560 \text {, leads to lower TXA2 concentration and protects kidneys from AKI. }\end{array}$ \\
\hline $\begin{array}{l}\text { (Nasrallah et al., 2014, 2016; } \\
\text { Nasrallah et al., 2015; Nasral- } \\
\text { lah et al., 2001; Nasrallah et } \\
\text { al., 2007) }\end{array}$ & Mice & $\begin{array}{l}\text { Blockade of EP1, EP3 and EP4 PGE2 receptors may be useful in inhibiting } \\
\text { renal damage in CKD. } \\
\text { COX2-mPGEsynthase 1- PGE2 pathway is related to diabetic nephropathy, } \\
\text { hyperfiltration, fibrosis, apoptosis, adiposity, dyslipidemia, and atherogene- } \\
\text { sis. }\end{array}$ \\
\hline (Olesen et al., 2011) & Rats & $\begin{array}{l}\text { EP2 and EP4 agonists increase water channel aquaporin-2 phosphorylation } \\
\text { and can partially compensate for a nonfunctional vasopressin type-2 recep- } \\
\text { tor. }\end{array}$ \\
\hline (Park et al., 2009) & Rats & 20-HETE plays an important role in the development of cysts in ADPKD. \\
\hline (Regner et al., 2009) & Rats & $\begin{array}{l}\text { Drugs that affect } 20-H E T E \text { may be useful in AKI treatment. Administration } \\
\text { of } 20-H E T E \text { analogues (HEDE and HEDGE) results in better urine output and } \\
\text { sodium excretion. }\end{array}$ \\
\hline (Spurney et al., 1992) & Mice & $\begin{array}{l}\text { TXA2 is an important agent in decreasing renal function in the model of } \\
\text { lupus nephritis. }\end{array}$ \\
\hline (Srivastava et al., 2014) & Rats & $\begin{array}{l}\text { Higher expression of COX 2, EP2 receptor and higher biosynthesis of PGE2 } \\
\text { lead to albuminuria due to the change in the structure of podocytes. }\end{array}$ \\
\hline (Uriu et al., 1994) & Rats & $\begin{array}{l}\text { TXA2 plays an important role in the progression of renal injury in diabetes } \\
\text { by modulating renin angiotensin system and increasing urinary albumin } \\
\text { excretion. }\end{array}$ \\
\hline (Vukicevic et al., 2006) & Rats & $\begin{array}{l}\text { PGE2 decreases tubular necrosis and quantity of apoptotic cells via EP4 } \\
\text { receptor. PGE } 2 \text { plays an important role in CKD mainly via both, EP } 2 \text { and } 4 \\
\text { receptors. }\end{array}$ \\
\hline (Wang et al., 2015) & Mice & $\begin{array}{l}\text { Chronic kidney disease predisposes to cardiovascular accidents because of } \\
\text { increased concentration of TXA } 2 .\end{array}$ \\
\hline (Wang et al., 2007) & Mice & $\begin{array}{l}\text { PGI2 plays an important protective role in AKI caused by endotoxemia, by } \\
\text { improving the function of kidneys in PGI2-CAMP-renin pathway. }\end{array}$ \\
\hline (Averna et al., 2001) & $\begin{array}{l}65 \text { patients after renal } \\
\text { transplantation }\end{array}$ & $\begin{array}{l}\text { Patients treated with } \\
\text { cyclosporine have a higher cardiovascular risk because cyclosporine incre- } \\
\text { ases } \\
\text { endothelium and platelet activation. Administration of drugs which may de- } \\
\text { crease or eliminate thromboxane-dependent platelet activation in vivo may } \\
\text { provide the risk of cardiovascular events reduction in the kidney recipients. }\end{array}$ \\
\hline (Courivaud et al., 2009) & $\begin{array}{l}603 \text { renal transplant re- } \\
\text { cipients }\end{array}$ & $\begin{array}{l}\text { A G }>C \text { polymorphism in COX } 2 \text { gene promoter leads to decreased COX } 2 \\
\text { enzyme production and the concentration of PGE } 2 \text { decreases significantly. }\end{array}$ \\
\hline (Dreisbach et al., 2014) & $\begin{array}{l}262 \text { African American } \\
\text { patients with CKD }\end{array}$ & 20-HETE plays an important role in the development of cysts in ADPKD. \\
\hline (Gainza et al., 2006) & $\begin{array}{l}38 \text { patients on continu- } \\
\text { ous renal replacement } \\
\text { therapy }\end{array}$ & $\begin{array}{l}\text { Epoprostenol may be used in renal replacement therapies either alone or } \\
\text { with heparin. }\end{array}$ \\
\hline (Imanishi et al., 1990) & $\begin{array}{l}5 \text { patients with chronic } \\
\text { vascular rejection after } \\
\text { kidney transplantation }\end{array}$ & $\begin{array}{l}\text { Thromboxane A2 synthetase inhibitor, called OKY-046, improved graft func- } \\
\text { tion after chronic rejection of kidney. }\end{array}$ \\
\hline
\end{tabular}




\begin{tabular}{|c|c|c|}
\hline (Klawitter et al., 2014) & 110 patients with ADPKD & $\begin{array}{l}\text { Blockade of 20-HETE production can be a useful strategy in treatment of } \\
\text { ADPKD. }\end{array}$ \\
\hline (Koyama et al., 2015) & 112 CKD patients & $\begin{array}{l}\text { Beraprost sodium- PGI2 analogue may improve renal function in patients } \\
\text { with CKD suffering from glomerular disease and nephrosclerosis. }\end{array}$ \\
\hline (Smith et al., 1992) & $\begin{array}{l}11 \text { male } \\
\text { cyclosporine-treated renal } \\
\text { allograft recipients with } \\
\text { toxicity symptoms during } \\
\text { treatment }\end{array}$ & $\begin{array}{l}\text { Inhibiting the biosynthesis of thromboxane might decrease the nephroto- } \\
\text { xicity of cyclosporine. }\end{array}$ \\
\hline (Stępniewska et al., 2017) & $\begin{array}{l}145 \text { patients with CKD: on } \\
\text { conservative treatment, } \\
\text { on peritoneal dialysis } \\
\text { and undergoing chronic } \\
\text { haemodialysis }\end{array}$ & Patients on peritoneal dialysis have higher levels of $12-\mathrm{HETE}$. \\
\hline (Swartz et al., 1988) & $\begin{array}{l}63 \text { ESRD patients with } \\
\text { active or recently active } \\
\text { bleeding }\end{array}$ & $\begin{array}{l}\text { The efficiency of hemodialysis with epoprostenol was as good as with hep- } \\
\text { arin, in the matter of blood urea nitrogen and creatinine decrease. }\end{array}$ \\
\hline
\end{tabular}

Abbreviations: AKI, acute kidney injury; ADPKD, autosomal dominant polycystic kidney disease; CKD, chronic kidney disease; $\mathrm{CAMP}_{\text {, }} \mathrm{Cyclic}$ adenosine monophosphate; COX, cyclooxygenase; ESRD, end-stage renal disease; EPO, erythropoietin; GFR, glomerular filtration rate; HEDE, 20-hydroxyeicosa-5(Z), 14(Z)-dienoic acid;HEDGE, N-[20-hydroxyeicosa-5(Z),14(Z)-dienoyl]glycine; HETE, hydroxyeicosatetraenoic acid; PGE2, prostaglandin E2; PGI2, prostaglandin I2; TXA2, thromboxane A2

ing changes in renal morphology and may become a new treatment strategy for hereditary nephrogenic diabetes insipidus (Li et al., 2009). Another prostaglandin, PGI2, is involved in the maintenance of the GFR level, regulation of renin release and homeostasis of sodium and blood pressure. Last but not least, there is thromboxane A2 which can mediate vasoconstriction induced by angiotensin II and regulates sodium excretion. Results from studies on Wistar-Kyoto and Sprague-Dawley rats had shown that TXA2 might contribute to renal vasoconstriction. Inhibition of TXA2 production, on the other hand, results in vasodilatation (Chatziantoniou et al., 1990; Badahman \& Wilson, 1994; Cediel et al., 2002; Sałata \& Dołegowska, 2014). Moreover, thromboxane B2, which is a metabolite of TXA2, acts as a vasoconstrictor and contributes to angina pectoris and the hepatorenal syndrome (Lewy et al., 1980; Zipser et al., 1983). The natriuretic function of the COX pathway products is regulated via the tumor necrosis factor (TNF) pathway. A furosemide-sensitive $\mathrm{Na}-\mathrm{K}-\mathrm{Cl}$ cotransporter (NKCC2 isoform) in the kidneys accounts for almost all luminal $\mathrm{NaCl}$ reabsorption in the thick ascending limb of the Henle's loop. Activity of this transport protein is regulated by humoral factors, but also depends on TNFalpha which acts in the COX2-PGE2 and COX-independent pathways. Both mechanisms contribute to a decreased expression of NKCC2 and as a result decreased $\mathrm{NaCl}$ reabsorption (Ferreri et al., 2012). Activity of COX in the kidneys depends on salt loading. COX 2 expression is associated with high-salt loading which has been confirmed in medullary interstitial cells. A high salt concentration does not affect the COX1 expression (Ye et al., 2006). Moreover, COX 2 expression is also regulated by PGE 2 action on its EP3 receptor. This mechanism depends on the negative feedback in the Henle's loop (Vio et al., 2012).

\section{The LOX pathway}

Lipoxygenases are enzymes producing HPETE acids - another type of eicosanoids. HPETE acids are transformed into HETE acids by a glutathione peroxidase. If there is cooperation of two lipoxygenases- 5-LOX and 12- or 15 LOX, lipoxines are being produced. 5-LOX is also a key enzyme in leukotriene A4 (LTA4) production. Next enzyme, leukotriene hydrolase, turns leukotriene A4 into LTB4, which is capable to interact with a LTB4 receptor. Lipoxygenases are located in different parts of kidneys. 5-LOX is commonly expressed in the glomerulus and outer medullary vasa recta. 12-LOX is expressed in the glomerulus. The last one, 15-LOX, is found in the distal part of nephron-collecting ducts. HETE acids take part in blood pressure regulation. LTB4 is known as a chemotactic substance (Dołegowska \& Chlubek, 2002). It plays a role in leukocytes' aggregation and adhesion to endothelium and in decreasing the eGFR rate. In contrast, lipoxines are anti-inflammatory molecules. Lipoxines stop the LTB4 dependent adhesion. An increasing concentration of lipoxines plays a key role in limitation of the inflammation process (Reinhold et al., 2006; Нao \& Breyer, 2007; Sałata \& Dołęgowska, 2014).

\section{The Cytochrome P-450 pathway}

Cytochrome P-450 hydroxylase and epoxygenase are the final two key enzymes in the eicosanoids' production. Their activity leads to generation of 20-HETE and EETs. These enzymes are located in the renal micro-vessels. 20-HETE and EETs regulate the renal microvascular function. 20-HETE is known as the constrictor of afferent arterioles. EETs work as endothelium dependent hyperpolarizing factors. They activate smooth muscle cells through their impact on large-conductance, calcium-activated $\mathrm{K}^{+}$channels in cAMP and protein kinase A dependent mechanisms. In contrast, 20-HETE inhibits the function of these channels. 20-HETE and EETs are also known for their natriuretic function. 20-HETE inhibits activity of the $\mathrm{Na}^{+} / \mathrm{K}^{+}$-ATPase in the proximal tubule and the $\mathrm{Na}^{+}-\mathrm{K}^{+}-2 \mathrm{Cl}^{-}$co-transporter in the thick ascending limb of Henle's loop. EETs inhibit epithelial sodium channel $(\mathrm{ENaC})$ activity in the collecting duct, lower blood pressure and have renoprotective properties (Hao \& Breyer, 2007; Williams et al., 2007; Dennis \& Norris, 2015; Fan et al., 2015; Imig, 2013, 2015). They are degraded by a cytosolic epoxide hydrolase. Use of an inhibitor of this enzyme, called cis-4-[4-(3-adamantan-1-yl-ureido)-cyclohexyloxy]-benzoic acid (c-AUCB), in a rat study had shown that such therapy successfully increased the concentration of EETs, improved renal blood flow and increased natriuresis (Sporková et al., 2011). Prostaglandins and epoxyeicosatetraenoic acids also mediate the connecting tubule- glomerular feedback (CTGF). CTGF is a mechanism where an increase in sodium concentration in the connecting tubule causes 
dilatation of the afferent arteriole. This phenomenon is mediated by prostaglandin E2 which is released from the connecting tubule and binds its EP4 receptor (Ren et al., 2013).

Eicosanoids play an important role in regulating physiological processes, such as the pro-inflammatory response, dilatation of vessels and signal transduction. They influence renal haemodynamics and glomerular filtration rate. Eicosanoids are also involved in the pathogenesis of chronic kidney disease (CKD), acute kidney injury, hypertension, diabetes, metabolic syndrome and cardiovascular disease (CVD), acting as paracrine and inflammatory mediators (Zhao, 2013; Zhao et al., 2015; Chen et al., 2016).

\section{EICOSANOIDS IN THE ACUTE KIDNEY INJURY (AKI)}

\section{Hypovolemia}

It has been proven that the AKI risk is higher when the nonsteroidal anti-inflammatory drugs (NSAIDs) and COX2 blockers are used. AKI caused by hypovolemia is characterized by higher activity of the renin- angiotensin cascade, which disturbs the balance between vasoconstriction and vasodilatation (Nørregaard et al., 2015). PGE 2 plays an important role in AKI acting via the EP4 receptor and decreasing the quantity of apoptotic cells and tubular necrosis (Vukicevic et al., 2006). Studies in rabbits had shown that the concentration of PGE2 in cortical tissue of kidneys was increased in AKI because of its decreased metabolism. (Chaudhari \& Kirschenbaum, 1983). It is considered that thromboxane A2 (TXA2) could be an important agent in AKI caused by hypovolemia. Studies in rats with the use of sulotroban, which is a specific TXA2 receptor antagonist, had shown that sulotroban was able to maintain the eGFR level at physiological ranges even under hypovolemic conditions. According to the presented test, sulotroban could stop TXA2 dependent vasoconstriction in the early phase of AKI (Kramer et al., 1993). Other drugs might be the reason of hypotension-induced AKI. Iloprost is a prostacycline (PGI2) analogue. It is used in the treatment of severe peripheral arterial disease. It is useful and effective because of its vasodilatatory and anti-aggregant functions. However, this drug can be dangerous because of a possibility of causing renal ischemia, which may result in nonoliguric AKI. The risk factors of this condition include smoking and low diastolic blood pressure (Uyar et al., 2016). Still, the same drug can decrease the risk of contrast induced nephropathy by $70 \%$ in patients with impaired renal function. Intravenous iloprost administration results in reversing the eGFR rate loss after contrast administration (Spargias et al., 2009). Also, 20-HETE exerts protective effect on the kidney during AKI caused by ischemia. The drugs that affect 20-HETE may be useful in AKI treatment. Administration of 20-HETE analogues to rats results in a better urine output and sodium excretion. In the rat model, 20-HETE analogues act via the blockade of sodium tubular transport (Regner et al., 2009; Roman et al., 2011).

\section{Endotoxemia}

Endotoxemia may be another reason for AKI. Studies in adult male Munich-Wistar rats had shown that an E. coli endotoxin can be responsible for decreasing the eGFR and filtration fraction. Stimulation of the TXA2 biosynthesis andother products of cyclooxygenase me- tabolism in the kidney are the reason for this phenomenon (Badr et al., 1986). On the other hand, it was reported in the mice model that a decreased activity of COX1 after administration of its inhibitor, called SC-560, provides lower TXA2 concentration and as a result protects the kidneys from AKI. It suggests that thromboxane A2 is responsible for the development of AKI during endotoxemia because of COX1 activation (Mederle et al., 2015). In contrast to TXA2, in the mice model, PGI2 plays an important protective role in AKI caused by endotoxemia by improving the function of kidneys in the PGI2-cAMP-renin pathway (Wang et al., 2007).

\section{Obstructive nephropathy}

Obstructive nephropathy is a type of AKI caused by the structural or functional hindrance of normal urine flow. During this state, COX2 expression is increased and prostaglandins and thromboxane are being generated. It is considered that PGE2/EP4 receptors might be a possible target in the treatment of obstructive nephropathy. Studies with mice subjected to $24 \mathrm{~h}$ bilateral ureteral obstruction (BUO) had shown that blockade of COX2 expression results in inhibiting the down-regulation of expression of the water channel proteins aquaporin 2 (AQP2) and aquaporin 3 (AQP3) in the renal cortex of examined animals (Nørregaard et al., 2005; Nilsson et al., 2012; Nørregaard et al., 2015). Another study performed with wild-type mice with unilateral ureteral obstruction (UUO) had shown that the EP4 receptor is a possible target in preventing fibrosis by stopping the inflammatory response (Nakagawa et al., 2012).

\section{EICOSANOIDS IN THE CHRONIC KIDNEY DISEASE (CKD)}

PGE 2 plays an important role in CKD mainly via both, the EP 2 and 4 receptors. In rat models of CKD, prostaglandins are able to increase GFR and preserve the kidney function. EP2 receptor agonist may possibly increase the survival rate of kidney while the EP4 receptor agonist provided less glomerular sclerosis, better preservation of proximal and distal tubules and blood vessels and less apoptotic cells (Vukicevic et al., 2006). It has been highlighted in mice studies that the chronic kidney disease predisposes to cardiovascular accidents because of increased concentration of TXA 2 which activates its receptors and contributes to the generation of reactive oxygen species (ROS). This results in bigger endothelial activation, leads to microvascular remodeling and might be the reason of cardiovascular accidents (Wang et al., 2015). Another study on mice had shown that TXA2 is an important agent in decreasing the renal function in the model of lupus nephritis. Administration of TXA2 receptor blocker led to higher GFR rate. The use of GR32191-TXA2 receptor specific antagonist reduced the severity of proteinuria and interstitial inflammation. It also decreased the concentration of thromboxane A2 metabolites in urine, similarly to the quantity of IgG glomerular deposits (Spurney et al., 1992).

$\mathrm{TXA}_{2}$ is mainly synthesized in the blood platelets and leads to their activation, aggregation and vasoconstriction. It is also produced by the kidney mesangial cells and podocytes. In glomerulonephritis, cyclosporine overdosing or kidney graft rejection, it causes a decrease in renal blood flow due to afferent and efferent arterioles constriction, contraction of mesangial cells, injury of the endothelium, deposition of fibrin and extracellular matrix proteins in glomeruli and mesangium, and the progression of kidney failure. Patients with CKD have higher 
plasma $\mathrm{TXA}_{2}$ concentrations than healthy individuals. As a result, patients in advanced stages of CKD are predisposed to thrombotic events and accelerated arteriosclerosis. The concentration of $\mathrm{TXA}_{2}$ also depends on the type of renal replacement therapy in the end-stage renal disease (ESRD). Haemodialysis treatment causes considerable decrease in the TXA 2 level which appears to be lower than in peritoneal dialysis (PD) and in conservatively treated patients. It is caused by increased oxidative stress during the haemodialysis procedure and platelet impairment in the uremic environment (Zhao \& Lint, 2014; Stępniewska et al., 2017).

TRK-100STP, which is a form of drug called Beraprost, a sodium-PGI2 analogue, may improve renal function, especially in patients with CKD suffering from glomerular disease and nephrosclerosis. TRK-100STP is considered to have a potential therapeutic effectiveness (Swartz et al., 1988; Koyama et al., 2015). Another PGI2 analogue - epoprostenol - is regarded as a possible antithrombotic factor. Studies have shown thatefficiency of hemodialysis with epoprostenol was equally good as the one with heparin, in the matter of blood urea nitrogen and creatinine decrease. During hemodialysis with PGI 2 , bleeding was reduced up to $50 \%$, especially in th high risk cases. The incidence of hypotension was similar during treatment with PGI2 and heparin. Administration of epoprostenol did not cause significant vasodilatatory episodes. A successful completion of the full, prospectively prescribed hemodialysis with PGI 2 was slightly lower than with heparin (82\% versus 93\%) (Swartz et al., 1988). It was confirmed that epoprostenol may be used in the renal replacement therapies either alone or with heparin, depending on whether there is a thrombocytopenia and an increased risk of bleeding or a state of hypercoagulability (Gainza et al., 2006). Some studies with mice had shown that blockade of EP1, EP3 and EP4 PGE2 receptors may be useful in inhibiting the renal damage in CKD by slowing the progression of glomerular and tubular injuries (Nasrallah et al., 2001; Nasrallah et al., 2014; Nasrallah et al., 2015).

\section{Diabetes}

One of the main causes of CKD is diabetes, which leads to a diabetic nephropathy. PGE2 concentration in diabetes is elevated. COX2-mPGEsynthase 1-PGE2 pathway is connected with diabetic nephropathy, hyperfiltration, fibrosis, apoptosis, adiposity, dyslipidemia, and atherogenesis. Moreover, this pathway plays an important role in the development of a metabolic syndrome in the mice model (Nasrallah et al., 2007; Nasrallah et al., 2016). A study with animal models had shown increased activity of enzymes catalyzing the 20-HETE generation in renal vessels in obesity and diabetes, whichmay be associated with the development of hypertension (Zhao et al., 2015; Chen et al., 2016).

TXA2 plays an important role in the progression of renal injury in diabetes. It modulates the renin angiotensin system and increases urinary albumin excretion. Studies in rats with streptozocin induced diabetes indicated that inhibition of the EP1 receptor may prevent the progression of diabetic nephropathy. Inhibition of this receptor leads to decreased mesangial expansion, decreased transcriptional activation of transforming growth factorbeta (TGF-beta) and fibronectin, and complete suppression of proteinuria. Using EP 1 receptor blocker alone decreases glomerular hypertrophy and proteinuria, while using EP1 blocker and aspirin decreases mesangium expansion as well (Uriu et al., 1994; Makino et al., 2002)
LOX products may also play a role in diabetic nephropathy. A study on mice with streptozocin induced diabetes had shown an increased level of 12/15 LOX and oxidative stress. It was suggested that 12/15LOX inhibition could improve renal function by suppressing inflammation and kidney injury. One of the 12LOX products - 12-HETE is linked to development of hypertension along with diabetic nephropathy (Hao \& Breyer, 2007; Klawitter et al., 2014). Patients on peritoneal dialysis, which predisposes them to higher plasma glucose concentration, have also higher levels of 12-HETE. This compound has been proven to have prothrombotic and proinflammatory properties (Zhao et al., 2015; Stępniewska et al., 2017).

\section{ADPKD}

Patients with the autosomal dominant polycystic kidney disease (ADPKD) have higher levels of inflammatory activation. It is hypothesized that increased activity of COX, LOX and CYP 450 enzymes, as well as biosynthesis of their products, remains one of the major causes of this condition. In ADPKD the production and concentration of 20-HETE is increased which is related to a lower GRF rate. An increased level of angiotensin II increases the 20-HETE concentration. It is possible that 20-HETE plays an important role in the development of cysts in ADPKD. Because of this, 20-HETE is considered as a possible biomarker of the disease. Moreover, blockade of the 20-HETE production can be a useful strategy in the ADPKD treatment in the rat model (Park et al., 2009; Dreisbach et al., 2014; Klawitter et al., 2014). Even though PGE2 increases erythropoietin (EPO) concentration, and as a result decreases the anemia after renal mass reduction, it also increases the inflammatory state and provokes renal dysfunction. In the cystic kidney rat model, it has been stated that after reduction in renal mass, there was renal blood flow reduction, elevation in blood pressure and proteinuria with no changes in GFR (Kang et al., 2000; Jia et al., 2012). It is regarded that both, the diabetic nephropathy and ADPKD, are syndromes with glomerular hyperfiltration. In these states there is an increased fluid flow shear stress which results in a higher expression of COX 2, EP2 receptor and higher biosynthesis of PGE2. In the rat model, all of these processes lead to albuminuria because of the change in the structure of podocytes (Helal et al., 2012; Srivastava et al., 2014).

\section{EICOSANOIDS IN RENAL TRANSPLANTATION}

Presence of urinary PGE2 is considered as a sign of successful renal transplantation. In contrast, a lower PGE 2 production results in a worse graft survival. A $\mathrm{G}>\mathrm{C}$ polymorphism in the COX 2 gene promoter leads to a decreased expression of the COX 2 gene and thus lower COX2enzyme level results in a significant PGE 2 concentration decrease (el-Sharabasy \& el-Naggar, 1991; Courivaud et al., 2009).

Moreover, there is an increased coagulative activation and biosynthesis of thromboxane during kidney transplantation. An increased 20-HETE and TXA 2 synthesis is a sign of ischaemia - reperfusion injury, which is caused by increased oxidative stress during the procedure and results in a delayed graft function after the surgery (Zhao, 2013; Chen et al., 2016). It has been reported that concentration of 11-dehydro-TXB2 - which is an indicator of TXA 2 biosynthesis- is elevated after transplantation. Patients who are treated with cyclosporine have a 
higher cardiovascular risk because cyclosporine may increase the activation of endothelium and as the consequence increases the level of TXA 2 and platelet activation. Drugs which decrease the thromboxane dependent activation of platelets might be considered as potentially useful in a group of patients after renal transplantation (Averna et al., 2001). Inhibiting the biosynthesis of thromboxane might decrease the nephrotoxicity of cyclosporine (Smith et al., 1992). Administration of thromboxane A2 synthetase inhibitor called OKY-046, has improved the graft function in chronic kidney rejection. It also decreased proteinuria (Imanishi et al., 1990).

A study in dogs with renal allotransplantation had shown that the LOX products, such as 12-HETE, are biosynthesized in higher amounts by renal cortical tissue which undergoes rejection. This suggests that these products may also take part in the rejection process (Mangino et al., 1987).

\section{CONCLUSION}

Lipid and lipid- derived metabolites play an important role in the physiology and pathological processes in the kidneys. They are promising biomarkers in detecting acute kidney injury, nephrotoxicity, glomerulonephritis, and early stages of diabetic nephropathy, especially in the context of their participation in the inflammatory processes and oxidative stress. They may be considered as potential novel targets of therapy. However, the role of eicosanoids is still not fully clear and needs to be further explored in the future studies.

\section{REFERENCES}

Averna M, Barbagallo CM, Ganci A, Giammarresi C, Cefalù A B, Sparacino V, Davì G (2001) Determinants of enhanced thromboxane biosynthesis in renal transplantation. Kidney Int 59: 1574-1579. doi:10.1046/j.1523-1755.2001.0590041574.x

Badahman AH,Wilson TW (1994) A renal vasodilator effect of angiotensin II revealed by dual thromboxane inhibition. Can J Physiol Pharmacol 72: 632-636

Badr KF, Kelley VE, Rennke HG, Brenner BM (1986) Roles for thromboxane A2 and leukotrienes in endotoxin-induced acute renal failure. Kidney Int 30: 474-480

Burdan F, Chałas A \& Szumiło J (2006) Cyclooxygenase and prostanoids - biological implications. Postepy Hig Med Dosw (Online) 60: 129-141

Cediel E, Vázquez-Cruz B, Navarro-Cid J, de las Heras N, SanzRosa D, Cachofeiro V, Lahera V (2002) Role of endothelin-1 and thromboxane A2 in renal vasoconstriction induced by angiotensin II in diabetes and hypertension. Kidney Int Suppl 82: S2-S7. doi:10.1046/j.1523-1755.62.s82.2.x

Chatziantoniou C, Daniels FH, Arendshorst WJ (1990) Exaggerated renal vascular reactivity to angiotensin and thromboxane in young genetically hypertensive rats. Am J Physiol 259: F372-F382. doi:10.1152/ajprenal.1990.259.2.F372

Chaudhari A, Kirschenbaum MA (1983) Mechanism of increased renal prostaglandin E2 in uranyl nitrate-induced acute renal failure. Prostaglandins 26: 689-699

Chen H, Cao G, Chen DQ, Wang M, Vaziri ND, Zhang ZH, Zhao YY (2016) Metabolomics insights into activated redox signaling and lipid metabolism dysfunction in chronic kidney disease progression. Redox Biol 10: 168-178. doi:10.1016/j.redox.2016.09.014

Courivaud C, Bamoulid J, Loupy A, Deschamps M, Ferrand C, Le Corre D, Ducloux D (2009) Influence of cyclooxygenase-2 (COX2) gene promoter polymorphism -765 on graft loss after renal transplantation. Am J Transplant 9: 2752-2757. doi:10.1111/j.16006143.2009.02830.x

Câmara NO, Martins JO, Landgraf RG, Jancar S (2009) Emerging roles for eicosanoids in renal diseases. Curr Opin Nephrol Hypertens 18: 21-27. doi:10.1097/MNH.0b013e32831a9df7

Câmpean V, Theilig F, Paliege A, Breyer M, Bachmann S (2003) Key enzymes for renal prostaglandin synthesis: site-specific expression in rodent kidney (rat, mouse). Am J Physiol Renal Physiol 285: F19-F32. doi:10.1152/ajprenal.00443.2002
Dennis EA, Norris PC (2015) Eicosanoid storm in infection and inflammation. Nat Rev Immunol 15: 511-523. doi:10.1038/nri3859

Dołegowska B, Chlubek D (2002) Lipoxygenase superfamily - structure and function in metabolism. Postepy Biochem 48: 275-286 (in Polish)

Dreisbach AW, Smith SV, Kyle PB, Ramaiah M, Amenuke M, Garrett MR, Roman RJ (2014) Urinary CYP eicosanoid excretion correlates with glomerular filtration in African-Americans with chronic kidney disease. Prostaglandins Other Lipid Mediat 113-115: 45-51. doi:10.1016/j.prostaglandins.2014.08.002

el-Sharabasy MM, el-Naggar MN (1991) Prostaglandin E2 in renal transplant recipients. Acta Med Hung 48: 225-229

Fan F, Muroya Y, Roman RJ (2015) Cytochrome P450 eicosanoids in hypertension and renal disease. Curr Opin Nephrol Hypertens 24: 37-46. doi:10.1097/MNH.0000000000000088

Ferreri NR, Hao S, Pedraza PL, Escalante B, Vio CP (2012) Eicosanoids and tumor necrosis factor-alpha in the kidney. Prostaglandins Other Lipid Mediat 98: 101-106. doi:10.1016/j.prostaglandins.2011.11.002

Gainza FJ, Quintanilla N, Pijoan JI, Delgado S, Urbizu JM, Lampreabe I (2006) Role of prostacyclin (epoprostenol) as anticoagulant in continuous renal replacement therapies: efficacy, security and cost analysis. J Nephrol 19: 648-655

Hao CM, Breyer MD (2007) Physiologic and pathophysiologic roles of lipid mediators in the kidney. Kidney Int 71: 1105-1115. doi:10.1038/ sj.ki. 5002192

Helal I, Fick-Brosnahan GM, Reed-Gitomer B, Schrier RW (2012) Glomerular hyperfiltration: definitions, mechanisms and clinical implications. Nat Rev Nephrol 8: 293-300. doi:10.1038/nrneph.2012.19

Hoozemans JJ, Rozemuller JM, van Haastert ES, Veerhuis R, Eikelenboom P (2008) Cyclooxygenase-1 and -2 in the different stages of Alzheimer's disease pathology. Curr Pharm Des 14: 1419-1427

Imanishi M, Ikegami M, Nishioka T, Ishii T, Uemura T, Kunikata S, Kurita T (1990) The effects of thromboxane A2 synthetase inhibitor on chronic rejection of kidney transplantation. Nibon Hinyokika Gakekai Zasshi 81: 895-901

Imig JD (2013) Epoxyeicosatrienoic acids, 20-hydroxyeicosatetraenoic acid, and renal microvascular function. Prostaglandins Other Lipid Mediat 104-105: 2-7. doi:10.1016/j.prostaglandins.2013.01.002

Imig JD (2015) Epoxyeicosatrienoic acids, hypertension, and kidney injury. Hypertension 65: 476-482. doi:10.1161/HYPERTENSIONAHA.114.03585

Jia Z, Wang H, Yang T (2012) Microsomal prostaglandin E synthase 1 deletion retards renal disease progression but exacerbates anemia in mice with renal mass reduction. Hypertension 59: 122-128. doi:10.1161/HYPERTENSIONAHA.111.178897

Kang SH, Oyama TT, Kennefick TM, Thompson MM, Anderson S (2000) Impaired adaptation to renal mass reduction in the polycystic rat. Am J Kidney Dis 35: 923-929

Klawitter J, McFann K, Pennington AT, Abebe KZ, Brosnahan G, Cadnapaphornchai MA, Schrier RW (2014) Bioactive lipid mediators in polycystic kidney disease. J Lipid Res 55: 1139-1149. doi:10.1194/ jlr.P042176

Koyama A, Fujita T, Gejyo F, Origasa H, Isono M, Kurumatani H, Okada K, Kanoh H, Kiriyama T, Yamada S (2015) Orally active prostacyclin analogue beraprost sodium in patients with chronic kidney disease: a randomized, double-blind, placebo-controlled, phase II dose finding trial. BMC Nephrol 16: 165. doi:10.1186/s12882-0150130-5

Kramer HJ, Mohaupt MG, Pinoli F, Bäcker A, Meyer-Lehnert H, Schlebusch H (1993) Effects of thromboxane A2 receptor blockade on oliguric ischemic acute renal failure in conscious rats. $J$ Am Soc Nephrol 4: 50-57

Lewy RI, Wiener L, Walinsky P, Lefer AM, Silver MJ, Smith JB (1980) Thromboxane release during pacing-induced angina pectoris: possible vasoconstrictor influence on the coronary vasculature. Circulation 61: 1165-1171

Li JH, Chou CL, Li B, Gavrilova O, Eisner C, Schnermann J,Wess J (2009) A selective EP4 PGE2 receptor agonist alleviates disease in a new mouse model of $\mathrm{X}$-linked nephrogenic diabetes insipidus. $J$ Clin Invest 119: 3115-3126. doi:10.1172/JCI39680

Makino H, Tanaka I, Mukoyama M, Sugawara A, Mori K, Muro S, Nakao K (2002) Prevention of diabetic nephropathy in rats by prostaglandin E receptor EP1-selective antagonist. J Am Soc Nephrol 13: 1757-1765

Mangino MJ, Anderson CB, Deschryver K, Turk J (1987) Arachidonate lipoxygenase products and renal allograft rejection in dogs. Transplantation 44: 805-808

Mederle K, Meurer M, Castrop H, Höcherl K (2015) Inhibition of COX-1 attenuates the formation of thromboxane A2 and ameliorates the acute decrease in glomerular filtration rate in endotoxemic mice. Am J Physiol Renal Physiol 309: F332-F340. doi:10.1152/ajprenal.00567.2014

Nakagawa N, Yuhki K, Kawabe J, Fujino T, Takahata O, Kabara M, Ushikubi F (2012) The intrinsic prostaglandin E2-EP4 system of the 
renal tubular epithelium limits the development of tubulointerstitial fibrosis in mice. Kidney Int 82: 158-171. doi:10.1038/ki.2012.115

Nasrallah R, Hassouneh R, Hébert RL (2014) Chronic kidney disease: targeting prostaglandin E2 receptors. Am J Physiol Renal Physiol 307: F243-F250. doi:10.1152/ajprenal.00224.2014

Nasrallah R, Hassouneh R, Hébert RL (2016). PGE2, Kidney disease, and cardiovascular risk: beyond hypertension and diabetes. I Am Soc Nephrol 27: 666-676. doi:10.1681/ASN.2015050528

Nasrallah R, Hassouneh R, Zimpelmann J, Karam AJ, Thibodeau JF, Burger D, Hébert RL (2015) Prostaglandin E2 increases proximal tubule fluid reabsorption, and modulates cultured proximal tubule cell responses via EP1 and EP4 receptors. Lab Invest 95: 1044-1055. doi:10.1038/labinvest.2015.79

Nasrallah R, Laneuville O, Ferguson S, Hébert RL (2001) Effect of COX-2 inhibitor NS-398 on expression of PGE2 receptor subtypes in M-1 mouse CCD cells. Am J Physiol Renal Physiol 281: F123-F132. doi:10.1152/ajprenal.2001.281.1.F123

Nasrallah R, Xiong H, Hébert RL (2007) Renal prostaglandin E2 receptor (EP) expression profile is altered in streptozotocin and B6Ins2Akita type I diabetic mice. Am J Physiol Renal Physiol 292: F278F284. doi:10.1152/ajprenal.00089.2006

Nilsson L, Madsen K, Topcu SO, Jensen BL, Frøkiær J, Nørregaard $\mathrm{R}$ (2012) Disruption of cyclooxygenase- 2 prevents downregulation of cortical AQP2 and AQP3 in response to bilateral ureteral obstruction in the mouse. Am J Physiol Renal Physiol 302: F1430-F1439. doi:10.1152/ajprenal.00682.2011

Nørregaard R, Jensen BL, Li C, Wang W, Knepper MA, Nielsen S, Frøkiaer J (2005) COX-2 inhibition prevents downregulation of key renal water and sodium transport proteins in response to bilateral ureteral obstruction. Am J Physiol Renal Physiol 289: F322-F333. doi:10.1152/ajprenal.00061.2005

Nørregaard R, Kwon TH, Frøkiær J (2015) Physiology and pathophysiology of cyclooxygenase- 2 and prostaglandin E2 in the kidney. Kidney Res Clin Pract 34: 194-200. doi:10.1016/j.krcp.2015.10.004

Olesen ET, Rützler MR, Moeller HB, Praetorius HA, Fenton RA (2011) Vasopressin-independent targeting of aquaporin-2 by selective E-prostanoid receptor agonists alleviates nephrogenic diabetes insipidus. Proc Natl Acad Sci U S A 108: 12949-12954. doi:10.1073/ pnas.1104691108

Park F, Sweeney WE, Jia G, Akbulut T, Mueller B, Falck JR, Avner ED (2009) Chronic blockade of 20-HETE synthesis reduces polycystic kidney disease in an orthologous rat model of ARPKD. Am J Physiol Renal Physiol 296: F575-F582. doi:10.1152/ajprenal.90705.2008

Regner KR (2012) Dual role of microsomal prostaglandin E synthase 1 in chronic kidney disease. Hypertension 59: 12-13. doi:10.1161/HYPERTENSIONAHA.111.180034

Regner KR, Zuk A, Van Why SK, Shames BD, Ryan RP, Falck JR, Roman RJ (2009) Protective effect of 20-HETE analogues in experimental renal ischemia reperfusion injury. Kidney Int 75: 511-517. doi:10.1038/ki.2008.600

Reinhold SW, Vitzthum H, Filbeck T, Wolf K, Lattas C, Riegger GA, Krämer BK (2006) Gene expression of 5-, 12-, and 15-lipoxygenases and leukotriene receptors along the rat nephron. Am J Physiol Renal Physiol 290: F864-F872. doi:10.1152/ajprenal.00169.2005

Ren Y, D'Ambrosio MA, Garvin JL, Wang H, Carretero OA (2013) Prostaglandin E2 mediates connecting tubule glomerular feedback. Hypertension 62: 1123-1128. doi:10.1161/HYPERTENSIONAHA.113.02040

Roman RJ, Akbulut T, Park F, Regner KR (2011) 20-HETE in acute kidney injury. Kidney Int 79: 10-13. doi:10.1038/ki.2010.396

Sales KJ, Jabbour HN (2003) Cyclooxygenase enzymes and prostaglandins in pathology of the endometrium. Reproduction 126: 559-567

Sales KJ, Katz AA, Howard B, Soeters RP, Millar RP, Jabbour HN (2002) Cyclooxygenase-1 is up-regulated in cervical carcinomas: autocrine/paracrine regulation of cyclooxygenase-2, prostaglandin e receptors, and angiogenic factors by cyclooxygenase-1. Cancer Res $\mathbf{6 2}$ $424-432$

Sałata D, Dołęgowska B (2014) Bioactive lipids in kidney physiology and pathophysiology. Postepy Hig Med Dosw (Online) 68: 73-83. doi:10.5604/17322693.1086412

Schwab JM, Schluesener HJ, Laufer S (2003) COX-3: just another COX or the solitary elusive target of paracetamol? Lancet 361: 981982. doi:10.1016/S0140-6736(03)12841-3

Smith SR, Creech EA, Schaffer AV, Martin LL, Rakhit A, Douglas FL, Coffman TM (1992) Effects of thromboxane synthase inhibition with CGS 13080 in human cyclosporine nephrotoxicity. Kidney Int 41: 199-205
Smith WS, Murphy RC (2002) The eicosanoids: cyclooxygenase, lipoxygenase and epoxygenase pathways. In Biochemistry of lipids, lipoproteins, and membranes. Vance DE, Vance JE eds, 4th edn. vol. 36, pp 341371. Amsterdam London: Elsevier.

Spargias K, Adreanides E, Demerouti E, Gkouziouta A, Manginas A, Pavlides G, Cokkinos DV (2009) Iloprost prevents contrastinduced nephropathy in patients with renal dysfunction undergoing coronary angiography or intervention. Circulation 120: 1793-1799. doi:10.1161/CIRCULATIONAHA.109.863159

Sporková A, Kopkan L, Varcabová S, Husková Z, Hwang SH, Hammock BD, Cervenka L (2011) Role of cytochrome P-450 metabolites in the regulation of renal function and blood pressure in 2-kidney 1-clip hypertensive rats. Am J Physiol Regul Integr Comp Physiol 300: R1468-R1475. doi:10.1152/ajpregu.00215.2010

Spurney RF, Fan PY, Ruiz P, Sanfilippo F, Pisetsky DS \& Coffman TM (1992) Thromboxane receptor blockade reduces renal injury in murine lupus nephritis. Kidney Int 41: 973-982

Srivastava T, Alon US, Cudmore PA, Tarakji B, Kats A, Garola RE, Sharma M (2014) Cyclooxygenase-2, prostaglandin E2, and prostanoid receptor EP2 in fluid flow shear stress-mediated injury in the solitary kidney. Am J Physiol Renal Physiol 307: F1323-F1333. doi:10.1152/ajprenal.00335.2014

Stępniewska J, Dołęgowska B, Puchałowicz K, Gołembiewska E, Ciechanowski K (2017) Bioactive lipids derived from arachidonic acid metabolism in different types of renal replacement therapy. Chem Phys Lipids 206: 71-77. doi:10.1016/j.chemphyslip.2017.05.003

Swartz RD, Flamenbaum W, Dubrow A, Hall JC, Crow JW, Cato A (1988) Epoprostenol (PGI2, prostacyclin) during high-risk hemodialysis: preventing further bleeding complications. J Clin Pharmacol 28: $818-825$

Uriu K, Kaizu K, Hashimoto O, Komine N, Etoh S (1994) Acute and chronic effects of thromboxane A2 inhibition on the renal hemodynamics in streptozotocin-induced diabetic rats. Kidney Int 45: 794-802

Uyar ME, Yucel P, Ilin S, Bal Z, Yildirim S, Uyar AS, Sezer S (2016) Iloprost as an acute kidney injury-triggering agent in severely atherosclerotic patients. Cardiovasc J Afr 27: 128-133. doi:10.5830/CVJA2015-051

Vio CP, Quiroz-Munoz M, Cuevas CA, Cespedes C, Ferreri NR (2012) Prostaglandin E2 EP3 receptor regulates cyclooxygenase-2 expression in the kidney. Am J Physiol Renal Physiol 303: F449-F457. doi:10.1152/ajprenal.00634.2011

Vukicevic S, Simic P, Borovecki F, Grgurevic L, Rogic D, Orlic I, Paralkar VM (2006) Role of EP2 and EP4 receptor-selective agonists of prostaglandin $\mathrm{E}(2)$ in acute and chronic kidney failure. Kidney Int 70: 1099-1106. doi:10.1038/sj.ki.5001715

Wang C, Luo Z, Kohan D, Wellstein A, Jose PA, Welch WJ,Wang D (2015) Thromboxane prostanoid receptors enhance contractions, endothelin-1, and oxidative stress in microvessels from mice with chronic kidney disease. Hypertension 65: 1055-1063. doi:10.1161/HYPERTENSIONAHA.115.05244

Wang W, Zolty E, Falk S, Summer S, Stearman R, Geraci M, Schrier $R$ (2007) Prostacyclin in endotoxemia-induced acute kidney injury: cyclooxygenase inhibition and renal prostacyclin synthase transgenic mice. Am J Physiol Renal Physiol 293: F1131-F1136. doi:10.1152/ajprenal.00212.2007

Williams JM, Sarkis A, Lopez B, Ryan RP, Flasch AK, Roman RJ (2007) Elevations in renal interstitial hydrostatic pressure and 20-hydroxyeicosatetraenoic acid contribute to pressure natriuresis. Hypertension 49: 687-694. doi:10.1161/01.HYP.0000255753.89363.47

Ye W, Zhang H, Hillas E, Kohan DE, Miller RL, Nelson RD, Yang $\mathrm{T}$ (2006) Expression and function of COX isoforms in renal medulla: evidence for regulation of salt sensitivity and blood pressure. Am J Physiol Renal Physiol 290: F542-F549. doi:10.1152/ajprenal.00232.2005

Zhao YY (2013) Metabolomics in chronic kidney disease. Clin Chim Acta 422: 59-69. doi:10.1016/j.cca.2013.03.033

Zhao YY, Lint RC (2014) Metabolomics in nephrotoxicity. Adv Clin Chem 65: 69-89

Zhao YY, Vaziri ND, Lin RC (2015) Lipidomics: new insight into kidney disease. Adv Clin Chem 68: 153-175. doi:10.1016/ bs.acc. 2014.11 .002

Zipser RD, Radvan GH, Kronborg IJ, Duke R, Little TE (1983) Urinary thromboxane B2 and prostaglandin E2 in the hepatorenal syndrome: evidence for increased vasoconstrictor and decreased vasodilator factors. Gastroenterology 84: 697-703 